\title{
Importance of Humane Design for Sustainable Landscape
}

\author{
S. Toofan
}

\begin{abstract}
Realizing the environmental threats, real or potential, to the quality of life, environmental movements have begun in virtually all sectors of industrialized countries, including business, manufacturing, transportation, agriculture, and architecture. Sustainable landscape architecture is one of the most incredible fields of design at contemporary topics. Important problem that will be resolved in this research is finding standard spots and positions in urban landscape for coming to sustainable landscape. The main purpose of this article is investigation of humane factors for better design in all scales of landscape architecture, into special consideration to sustainability. The research method of this paper is "Descriptive Study", with two strategies: definition of keywords and discussion about them to receiving useful alternatives. Basic subjects had defined and then major objects had analyzed. Pay attention to new approach of sustainability and valuable position sustainable architectural research in contemporary landscape design is important result of this written.
\end{abstract}

Index Terms-Humane design, landscape, sustainability.

\section{INTRODUCTION}

The globalization of architectural styles, building technologies and urban space has dramatically impacted city design in the developing world. On the one hand the destruction of the patrimony of indigenously designed and developed urban places and spaces is accelerating: built environments which are culturally rooted, locally produced, and technologically adapted in time and space are being rapidly eroded. Their potential responsiveness to the needs of a changing social and functional world is largely ignored. Instead, unique built environments are being removed from their context and replaced by global forms and designs which are often poorly adapted to local needs and conditions [1]. Segregation of land uses removes the vitality created by mixed activity patterns. On the other hand, these pressures are product the place-identity of historic urban spaces and places, at once detaching them from their continuity with locality, space and time, whilst at the same time re-presenting them for global cultural consumption. These outcomes question the sustainability of new patterns and processes of urban design and the production of local space. They question how place identity is created, recreated and sustained [2].

The vast literature on cities and urbanization in the developing world has framed the sustainability discourse largely in terms of an environmental agenda preoccupied with 'green and brown' issues such as pollution, urban waste,

Manuscript received January 10, 2014; revised March 12, 2014.

S. Toofan is with Architecture, Department of Architecture, College of Art \& Architecture, Tabriz Branch, Islamic Azad University, Tabriz, Iran (e-mail: Sahar.toofan@iaut.ac.ir). energy consumption, transport and the urban footprint [3], [4]. Curiously, and with the recent exception of the compact city debates [5], this literature has largely neglected the challenge of designing cities as sustainable and live able places which can adapt their unique cultural identities and specific historic heritage to contemporary needs. Conservation and sustainability in relation to the patrimony and cultural heritage of the built environment are core themes.

Scientific research continues to provide information about the links between human health and environmental quality. Essential components of life-air, water, and food-provide potential pathways for contaminants to affect our health. World health organization said: "Health is a state of complete physical, mental and social well-being and not merely the absence of disease or infirmity". [6] Exposure to pollutants through the contamination of air, water, and soil has been linked to various health conditions such as cancer, cardiac and respiratory illness, reproductive problems and birth defects, nervous system disorders, allergic reactions, hypersensitivity, and decreased resistance to disease [7].

The environment is connected to everything in our lives. It is complex, made up of diverse interacting systems. Our interactions with the environment are also complex. Our health, economic prosperity, and way of life are all affected by the quality of our environment. We recognize its intrinsic value and the importance of natural spaces and biodiversity.

Humane design is the most important principle of sustainable design. While economy of resources and life cycle design deal with efficiency and conservation, humane design is concerned with the livability of all constituents of the global ecosystem, including plants and wildlife. This principle arises from the humanitarian and altruistic goal of respecting the life and dignity of fellow living organisms [8].

An essential role of landscape architecture is to provide built environments that sustain occupants' safety, health, physiological comfort, psychological well-being, and productivity. Because environmental quality is intangible, its importance has often been overlooked in the quest for energy and environmental conservation. Compounding the problem, many designers have been preoccupied with style and form-making, not seriously considering environmental quality in and around their built environments [8].

\section{DEFINITIONS}

\section{A. What is Sustainability?}

It is generally accepted that the trilogy of economy, environment and social equity are foremost components of the sustainability concept [9]. Sustainability is a broad term that generally means that a person or society lives within the means of what the Earth can provide over a long term. When 
a process is sustainable, it can be carried out over and over without negative effects on the environmental effects or high costs. The definition of Sustainability for the purposes of this Master Plan (United Nations World Commission on Environment and Development) is: "Sustainability meets the needs of the present without compromising the ability of future generations to meet their own needs."[10].

\section{B. What is Sustainable Development?}

World Commission on Environment and Development (WCED-1987) established the definition of sustainable development as "a development that meets the needs of the present generation without compromising the ability of future generations to meet their own needs" [10]. Since the term "sustainable development" came into use in the 1970s, it has been used to mean many different things - as have terms such as sustainable cities and sustainable urbanization. Although the original use of the term sustainable development was intended to place a higher priority on directly meeting human needs while considering development's environmental and ecological implications. If we go back to the term's original meaning, when applied to cities, it comes down to whether two goals can go together. Whether cities can be healthy, enjoyable, resilient places to live and ensure that the draw of their populations' consumption and enterprises' production on local, regional and global resources and sinks is not disproportionate [11]. In this context, Moore [12] claims that there is a triangular conflict among economy Fig. 1, ecology and equity as key sustainability contributors in terms of strategy achievement. A balance between development, property and resource discourses is required to achieve an integrated sustainability in an urban context. Such a balance has more opportunity to make the city more profitable, fairer and greener for stakeholders, developers and governors.

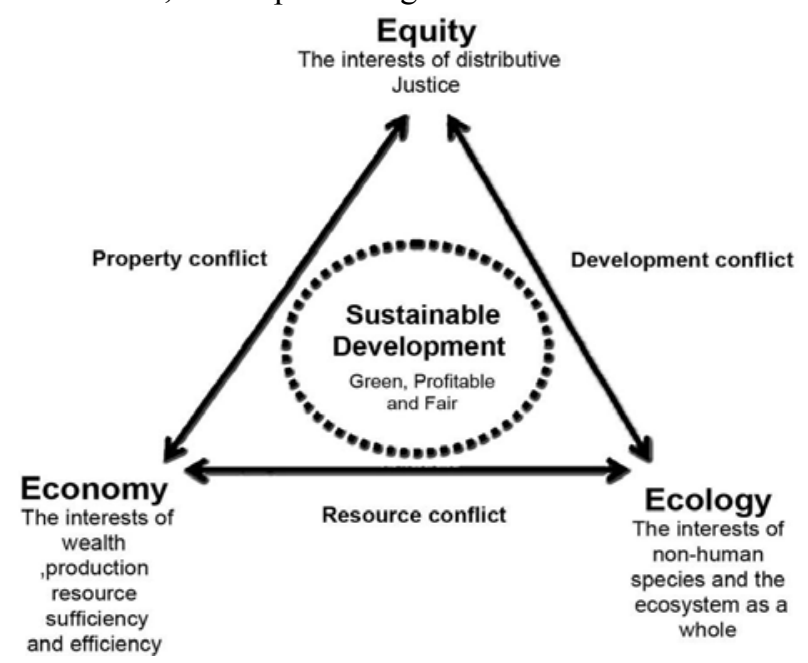

Fig. 1. Triangular conflict to achieve sustainability [12].

\section{What is Sustainable Cities?}

Designing Sustainable Cities in the Developing World introduces a new perspective on cities which is innovative in scale, content and objectives. In terms of scale, the mainstream urban literature and research on cities in the developing world is, of course, vast. Dominated by a number of recurring themes, these provide both a valuable context and potent insights to support our own perspective. Briefly these include: theories of urbanization; the political economy of cities and the form and consumption of space; demographic, social and spatial reconfiguration under conditions of globalization and structural adjustment; the dynamics of urban economies and the livelihoods of the mass of low income dwellers; urban poverty and environmental degradation; the scope of policy and intervention to manage rapid informal urbanization [13], [14]. Sustainability features strongly in the urbanization literature, but is preoccupied with macro scale processes, issues of governance and institutional capacity and the political economy of urban environmental sustainability [15]-[17].

Sustainable principles of urban development are categorized into management, social-economic and ecological subdivisions. Management principles include local International government responsibility with better environmental understanding, flexibility of environmental policies and long-term strategic visions. Socio-economical category includes appropriate technology and design, creating adequate environmental indicators, standard regulations, market connectedness, supporting by social acceptability and public participation. Ecological principles contain prevention-led actions, integrated activities, using minimum resources (renewable and recyclable), and producing minimum waste, respecting the environmental diversity and expanding local environmental research [18].

\section{What is Sustainable Landscape?}

Sustainable architecture is architecture that seeks to minimize the negative environmental impact of buildings by efficiency and moderation in the use of materials, energy, and development space. Sustainable architecture uses a conscious approach to energy and ecological conservation in the design of the built environment. The idea of sustainability, or ecological design, is to ensure that our actions and decisions today do not inhibit the opportunities of future generations.

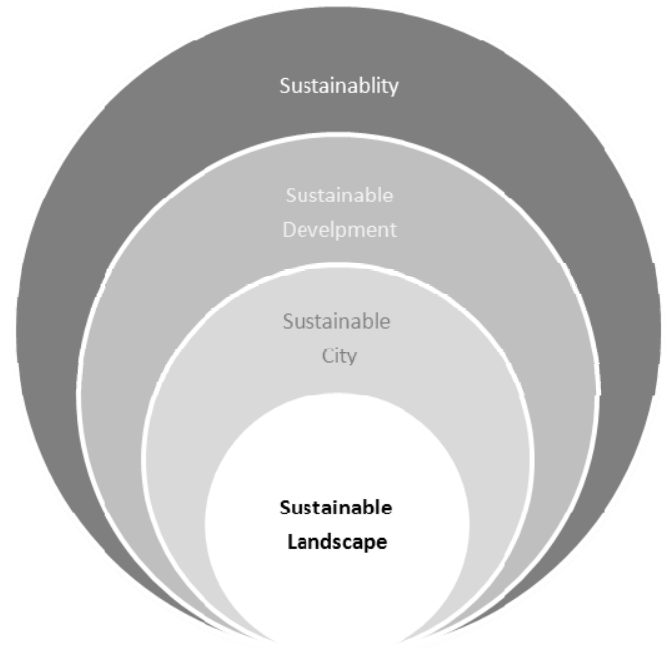

Fig. 2. Hierarchy of sustainability.

Sustainable landscape architecture is a category of sustainable design concerned with the planning and design of outdoor space. This can include ecological, social and economic aspects of sustainability. Sustainable landscape architecture creates ecological designs for the outdoor and urban environment. It begins with appropriate systems which address function, cost, energy efficiency, beauty, and 
environment. Sustainable landscape architecture is the integration of ecological, social, cultural, and economic factors in designing landscapes to help protect habitat, contribute to storm water management, conserve water, among other objectives. The current trend in the practice of landscape architecture is to find the balance of "aesthetics and function" required for Successful sustainable design.

Sustainable landscape architecture takes into account economic, social, and environmental aspects of landscapes. There are many different approaches to landscape sustainability, for example Fig. 2, but all would agree on a few key aspects. First, there is no right solution that will produce a sustainable landscape every time. Secondly, every proposal must be contextually responsive and specific. Finally, sustainable landscapes are not just about creating green spaces, but are about implementing design that can benefit both humans and ecosystems simultaneously [19].

\section{DisCUSSION AND RESULTS}

Harmonious integration of landscape and people, providing their food, energy, shelter and other material and non-material needs in a sustainable way [20]. Humane design is the most important principle of sustainable design. Humane design focus on enhancing the coexistence between buildings and the greater environment, and between buildings and their occupants and urban landscape. A landscape architect should minimize the impact of a landscape on its local ecosystem (existing topography, plants, and wildlife).

TABLE I: DESCRIPTIVE TABLE FOR COMING TO "DEVELOPED LIFE QUALITY"

\begin{tabular}{|c|c|c|}
\hline $\begin{array}{l}\text { Sustainable } \\
\text { Landscape }\end{array}$ & Goals & $\begin{array}{c}\text { Strategies } \\
\text { for } \\
\text { Humane Design }\end{array}$ \\
\hline $\begin{array}{l}\text { Economic } \\
\text { Growth }\end{array}$ & $\begin{array}{c}\text { Industrial } \\
\text { Development }\end{array}$ & $\begin{array}{c}\text { Tourism } \\
\text { Agriculture } \\
\text { Industrial Design }\end{array}$ \\
\hline $\begin{array}{c}\text { Worthy } \\
\text { Environment }\end{array}$ & $\begin{array}{c}\text { Energy } \\
\text { Conservation } \\
\text { Nature } \\
\text { Conservation }\end{array}$ & $\begin{array}{c}\text { Water Conservation } \\
\text { Trees Conservation } \\
\text { Material Conservation } \\
\text { Incorporate Reclaimed or } \\
\text { Recycled Materials } \\
\text { Avoid pollution contribution } \\
\text { Preservation of Natural } \\
\text { Conditions } \\
\text { Minimize Site Impact }\end{array}$ \\
\hline $\begin{array}{l}\text { Respect to People } \\
\text { (Humane } \\
\text { Design) }\end{array}$ & $\begin{array}{c}\text { Creating } \\
\text { Healthy Place } \\
\text { Enjoyable Place } \\
\text { Comfortable } \\
\text { Place }\end{array}$ & $\begin{array}{c}\text { Promote mixed use } \\
\text { development } \\
\text { Create pedestrian pockets } \\
\text { Provide for human-powered } \\
\text { transportation } \\
\text { Integrate design with public } \\
\text { transportation } \\
\text { Provide clean, fresh air } \\
\text { Provide thermal, visual, and } \\
\text { acoustic comfort } \\
\text { Accommodate persons with } \\
\text { differing physical abilities } \\
\text { Accommodate persons with } \\
\text { differing ages } \\
\text { Safety and Security (children \& } \\
\text { women) }\end{array}$ \\
\hline
\end{tabular}

Neighborhoods, cities, and entire geographic regions can benefit from cooperative planning to reduce energy and water demands. The result can be a more pleasant urban environment, free of pollution and welcoming to nature. As discussed previously, sustainable design need not preclude human comfort. Design should enhance landscape environments. This can improve productivity, reduce stress, and positively affect health and well-being.

As described in the introduction, this principle embodies three strategies: preservation of natural conditions, urban design and site planning, and design for human comfort. These strategies, in turn, yield specific design methods that will improve the sustainability of landscape architecture. The methods associated with the Urban Design and Site Planning strategy apply sustainability at a scale larger than the individual building. Sustainable landscape architecture on an urban scale must be designed to promote public transportation. Thousands of individual vehicles moving in and out of area with the daily commute create smog, congest traffic, and require parking spaces [8].

Sustainable development encourages the mixing of residential, commercial, office and retail space, such as Table I. People then have the option of living near where they work and shop. This provides a greater sense of community than conventional suburbs. The potential for 24-hour activity also makes an area safer. One aspect of sustainable design is its longevity. Landscapes that are durable and adaptable are more sustainable than those that are not. This adaptability includes welcoming people of different ages and physical conditions. The more people can use a landscape, the longer the landscape's useful life [8].

A sustainable City's quality of life is greatly enhanced by extensive parks and open space areas. From small urban parks, to national parks, to forests and parkways, to agricultural lands, to sport lands, the presence of nature, open space and habitat areas are essential. The preservation of open space and trees and natural environments is essential to the health of community. These areas provide opportunities for recreation, provide habitat for wildlife, and support alternative modes of travel. Parks and natural areas directly mitigate climate change by moderating temperatures from the urban heat island effect.

The urban garden is a key contributor to sustainability in a place named the City of Trees. Trees provide environmental and ecological benefits through improved air quality by storing carbon dioxide that would otherwise contribute to global warming, improving water quality by naturally filtering overland runoff, reducing flood risk through bank stabilization and increased water storage, and providing bird nesting habitat, see Table II. The urban garden contributes economic benefits by increasing property values and lowering building energy use by providing incidental shade. Trees improve public health and converting $\mathrm{CO} 2$ to oxygen.

Sustainability affects every level and scale of organization, from the entire planet to local neighborhoods and individuals. Public involvement and personal responsibility is vital to effectively planning actions and implementing solutions. A central goal of this focus area is to facilitate communication, public outreach and civic engagement on sustainability. Although the City has an important role in addressing climate change, residents and business must be inspired to take actions to reduce greenhouse gas emissions as well. The City 
should take the opportunity to work with citizens, businesses and community groups to implement personal and business oriented sustainability initiatives.

TABLE II: THE HIERARCHY OF SUSTAINABILITY

\begin{tabular}{|c|c|c|c|}
\hline & Perspective & Factors & Hierarchy \\
\hline 1 & Sustainability & $\begin{array}{l}\text { Economy } \\
\text { Environment } \\
\text { Equity }\end{array}$ & $\begin{array}{c}\text { Global } \\
\text { Development }\end{array}$ \\
\hline 2 & $\begin{array}{c}\text { Sustainable } \\
\text { Development }\end{array}$ & $\begin{array}{l}\text { Economy } \\
\text { Ecology } \\
\text { Humane Design }\end{array}$ & $\begin{array}{l}\text { Developed } \\
\text { Government }\end{array}$ \\
\hline 3 & Sustainable Cities & $\begin{array}{l}\text { Social Economy } \\
\text { Ecological } \\
\text { Subdivision } \\
\text { Urban Management }\end{array}$ & $\begin{array}{c}\text { Developed Urban } \\
\text { Planning }\end{array}$ \\
\hline 4 & Sustainable Landscape & $\begin{array}{l}\text { Economic Growth } \\
\text { Worthy Environment } \\
\text { Respect to People }\end{array}$ & $\begin{array}{c}\text { Developed Life } \\
\text { Quality }\end{array}$ \\
\hline
\end{tabular}

Through a wide variety of partner organizations-, in parks, in community centers, and in neighborhoods - the City can promote an ethic of conservation and stewardship, and encourage and empower people to take actions that improve environmental quality and quality of life in and around their neighborhoods [19]. (see Fig. 3).

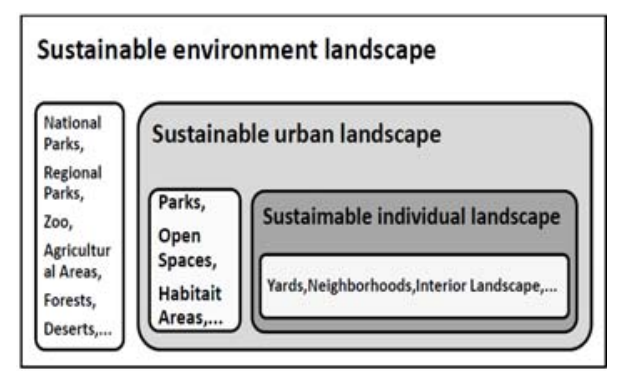

Fig. 3. Levels of sustainable landscape design.

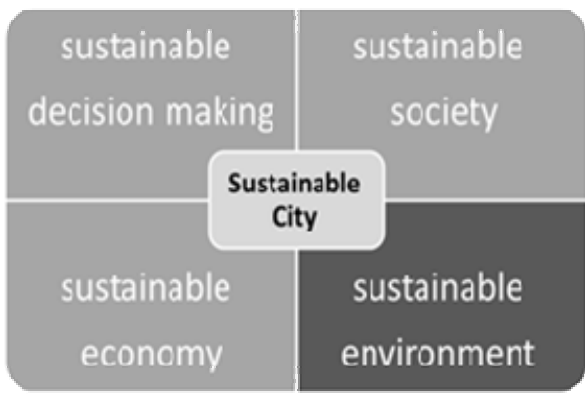

Fig. 4. Composition of sustainable city.

\section{CONCLUSION}

The Crucial fact about sustainability is that it is not a small phenomenon: there can be no such thing as a 'sustainable' hotel, tourist center, or landscape appliance, for the same reason that there can be no such thing as a one-person democracy or a single-company economy. Sustainability is a context, not instrumentation or a technology. In Fig. 4, sustainability of cities can be achieved by balancing four integrated factors: sustainable decision making, sustainable society, sustainable environment and sustainable economy.

The balance between these factors is totally related to the context potentials in local, regional and global scales. To achieve environmental sustainability in landscape sector, architects must be educated about environmental issues during their professional training. The current status of sustainable design in landscape architecture is that of an ethic rather than a science. While a change of lifestyles and attitudes toward the local and global environments is important, the development of scientific knowledge-bases that provide skills, techniques, and methods of implementing specific environmental design goals is urgent. To enhance environmental sustainability, a landscape must holistically balance and integrate all three principles - Sustainable Design, Economy of Resources, and Life Cycle Design - in design, construction, operation and maintenance, and recycling and reuse of architectural resources, Fig. 5. These principles comprise a conceptual framework for sustainable landscape architectural design.

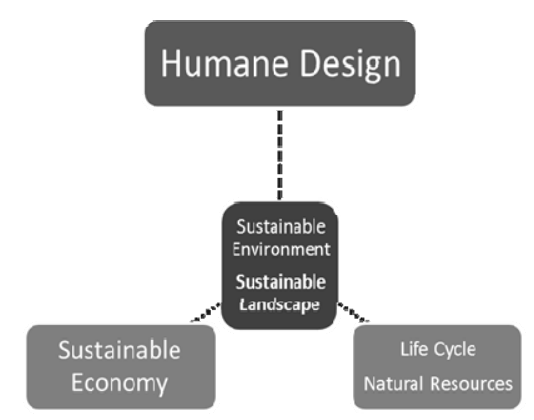

Fig. 5. Humane Design for creation sustainable landscape.

The study supports the proposal that a new framework can help inform a move towards a typology of sustainable landscape design that in turn can help architects develop and refine their approaches to sustainability.

The result is a common grouping of strategies for sustainable landscape design. There are overlaps or general themes in the principles that underpin the strategies as indicated in Table II and Table II. The principles can be more than a useful checklist and can define a sustainable philosophy for a landscape architecture.

For landscape architectural practices to move forwards, the author argues that the starting point is the definition of a philosophy and the establishment of a set of guiding principles reflected within a typology of sustainable landscape design.

People and their needs are main factor for designing sustainable landscape architecture, urban landscape, city open space humane design scale sustainable development environment at contemporary life.

\section{REFERENCES}

[1] A. D. King, Spaces of Global Cultures: Architecture Urbanism Identity, London: Routledge, 2004

[2] C. Hague and P. Jenkins, Place Identity, Participation and Planning, Oxford: Routledge.

[3] R. White, Urban Environmental Management: Environmental Change and Urbanisation, Chichester: John Wiley, 1994.

[4] D. Satterthwaite, Earthscan Reader in Sustainable Cities, London: Earthscan, 1999.

[5] M. Jenks and R. Burgess, Compact Cities: Sustainability and Urban Form in Developing Countries, London: E. and F. N. Spon, 2000.

[6] D. Sisam and M. Sisam, "Sustainable urbanism: aspects of a healthy city," presented at the Interna tional symposium \& academy awards, Design \& Health: Global Perspectives, Local Identities, Isabel Bader Theatre, University of Toronto, Canada, June 7-8, 2010.

[7] S. Ronald and C. D. Russell, "Towards a Sustainable Environment," Crown copyright, Canada: Province of Nova Scotia, 2003, pp. 12-28. 
[8] J. J. Kim and B. Rigdon, "Sustainable Architecture Module, Introduction to Sustainable Design," College of Architecture and Urban Planning, 1998, pp. 27-28.

[9] E. Chan and G. K. L. Lee, "Critical Factors for Improving Social Sustainability of Urban Renewal Projects," Social Indicators Research, vol. 85, no. 2, pp. 243-256, 2008.

[10] A. Soltani and E. Sharifi, "A case study of sustainable urban planning principles in Curitiba (Brazil) and their applicability in Shiraz (Iran)," International Journal of Development and Sustainability, vol. 1, pp. 120-134, Feb 2012

[11] D. Satterthwaite, "The Role of Cities in Sustainable Development," Sustainable Development Insights, Boston University, pp. 3-8, May 2010.

[12] S. A. Moore, Alternative Routes to the Sustainable City: Austin, Curitiba, and Frankfurt, Lexington Books: Lanham, 2007.

[13] S. Romaya and C. Rakodi, Building Sustainable Urban Settlements: Approaches and Case Studies in the Developing World, London: ITDG, 2002.

[14] R. Zetter and M. Hamza, Market Economy and Urban Change: Impacts in the Developing World, London: Earthscan, 2004.

[15] R. Burgess, M. Carmona, and T. Kolstee, The Challenge of Sustainable Development: Neo-liberalism and Urban Strategies in the Developing World, London: Zed, 1997.

[16] C. Pugh, Sustainability, the Environment and Urbanisation, London: Earthscan, 1996.

[17] R. Stren, R. White, and J. Whitey, Sustainable Cities: Urbanization and the Environment in International Perspective, Boulder $\mathrm{CO}$ Westview Press, 1992.
[18] G. Haughton and C. Hunter, Sustainable Cities, London: Routledge, 1994.

[19] C. Bean and C. H. Y. Mayla, "Standards in Sustainable Landscape Architecture," presented at the Seminar in Sustainable Architecture. Sustainable Landscape Architecture, University of Texas, 2009, pp. 101 .

[20] B. Mollison, Permaculture - A Designer's Manual, Sisters' Creek, Australia: Tagari Publications, 1988, p. 127.

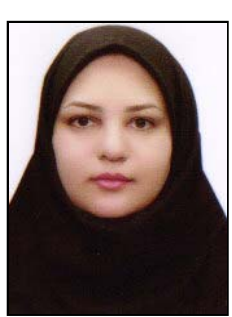

Sahar Toofan was born in Tabriz, Iran, in May 1979 She has received her M.A. degree in architecture from Islamic Azad University, Tabriz Branch, Iran in 2003, and M.Sc. degree in landscape architecture from Shahid Beheshti University, Tehran, Iran in 2007, and $\mathrm{Ph} . \mathrm{D}$. degree in architecture from Islamic Azad University, science and research Branch, Tehran, Iran in 2009. The major fields are landscape architecture, Islamic architecture, and Iranian traditional architecture.

She is staff member (assistant professor) at Department of Architecture, Art and Architecture faculty, Islamic Azad University, Tabriz Branch, Iran since 2003 until now. She had published more than 30 papers in journals and conferences.

Toofan owns memberships in some professional societies such as ICOM, Iranian Organization for Engineering of Building Province EAST Azerbaijan, Society of Architects of Tabriz, Iran. 